\title{
Variable stoichiometry and homeostatic regulation of bacterial biomass elemental composition
}

\author{
J. Thad Scott ${ }^{1,2 *}$, James B. Cotner ${ }^{1}$ and Timothy M. LaPara ${ }^{3}$ \\ 1 Department of Ecology, Evolution, and Behavior, University of Minnesota, St. Paul, MN, USA \\ ${ }^{2}$ Department of Crop, Soil, and Environmental Sciences, University of Arkansas, Fayetteville, AR, USA \\ ${ }^{3}$ Department of Civil Engineering, University of Minnesota, Minneapolis, MN, USA
}

\section{Edited by:}

Sonya Dyhrman, Woods Hole

Oceanographic Institution, USA

\section{Reviewed by:}

Vanessa Karel Michelou, Stanford

University, USA

Solange Duhamel, Woods Hole

Oceanographic Institution, USA

Thomas Chrzanowski, University of

Texas Arlington, USA

*Correspondence:

J. Thad Scott, Department of Crop, Soil, and Environmental Sciences,

University of Arkansas, Fayetteville, AR 72701, USA.

e-mail: jts004@uark.edu
Prokaryotic heterotrophs (hereafter, bacteria) represent a large proportion of global biomass, and therefore bacterial biomass stoichiometry likely exerts control on global phosphorus $(\mathrm{P})$, carbon $(\mathrm{C})$, and nitrogen cycling and primary productivity. In this study we grew recently isolated freshwater heterotrophic bacteria across an ecologically relevant range of resource $C: P$ ratios (organic $C$ to $P$ ratio in available resources) to quantify the $P$ requirements of these organisms and examine the degree to which they regulated their $P$ content under P-sufficient and P-deficient conditions. Bacterial biomass was only limited by $P$ when resource C:P was greater than 250 (by atoms). Bacterial C:P ranged from 71 to 174 under $P$ sufficiency and from 252 to 548 under P deficiency. Bacteria exhibited very little C:P homeostasis under P-sufficient growth conditions, greater C:P homeostasis under P-deficient conditions, and the ability of bacteria to outcompete one another in short-term experiments depended on a tradeoff between storing excess $\mathrm{P}$ for later use under P-deficient conditions or immediately using $P$ to produce more biomass. These results indicate that freshwater heterotrophic bacteria are not as P-rich as previously thought and that homeostatic regulation of $\mathrm{C}: \mathrm{P}$ stoichiometry depends on the individual taxa and what resource (organic $\mathrm{C}$ or available $\mathrm{P}$ ) is limiting bacterial growth. Individual bacterial populations can vary between strong $\mathrm{C}: \mathrm{P}$ homeostasis under $\mathrm{P}$ deficiency to virtually no $\mathrm{C}: \mathrm{P}$ homeostasis under $P$ sufficiency, but variation between taxa and the effect this has on competitive ability may dampen the signal in $\mathrm{C}: \mathrm{P}_{\mathrm{B}}$ at the bacterial community level. Nevertheless, the prevalence of homeostatic and non-homeostatic strategies in a bacterial community should have important implications for nutrient regeneration and carbon cycling.

Keywords: nutrient cycling, phosphorus, bacteria, autotroph-heterotroph, productivity, element ratios, carbon lability

\section{INTRODUCTION}

Prokaryotic heterotrophs (hereafter, bacteria) can influence the availability of phosphorus (P) in soils, lakes, and oceans (Cotner and Biddanda, 2002; van der Heijden et al., 2008), which effectively controls primary production in many ecosystems (Elser et al., 2007). Bacteria are thought to be substantial nutrient sinks because they often outcompete autotrophs for nutrients in nutrient-poor environments (Cotner and Wetzel, 1992; Nordin et al., 2004; Thingstad et al., 2008). However, competitive P uptake and immobilization by bacteria should only occur during P-deficient growth, when the organic carbon $(\mathrm{C})$ to $\mathrm{P}$ ratio in the available resources $\left(\mathrm{C}: \mathrm{P}_{\mathrm{R}}\right)$ is greater than the $\mathrm{C}: \mathrm{P}$ required for bacterial biomass $\left(\mathrm{C}: \mathrm{P}_{\mathrm{B}}\right)$.

There are very few data available on the stoichiometric requirements of bacteria in nature, particularly as it relates to resource ratios. Bacteria are often assumed to be nutrient-rich (Sterner and Elser, 2002) because their growth rates can be rapid, and rapid growth requires substantial P for DNA replication and ribosome production (Makino et al., 2003; Chrzanowski and Grover, 2008). Cleveland and Liptzin (2007) suggested that soil microbes were substantially more P-rich $(\mathrm{C}: \mathrm{P} \approx 60: 1)$ than terrestrial autotrophs
(C:P $\approx 900: 1-2500: 1)$. However, Cotner et al. (2010) found no difference in the elemental composition of bacterioplankton and phytoplankton growing along a gradient of $\mathrm{P}$ availability in lakes.

Although a number of factors, such as growth rate and temperature, can affect bacterial stoichiometry (Cotner et al., 2006; Chrzanowski and Grover, 2008), resource ratios may have the greatest influence (Chrzanowski and Kyle, 1996; Makino et al., 2003). But, the few studies that have explored the effect of resource ratios on bacterial stoichiometry were conducted using Escherichia coli (Makino et al., 2003) and Pseudomonas fluorescens (Chrzanowski and Kyle, 1996). These model organisms have grown for many generations on nutrient-rich laboratory media, perhaps altering their potential responses to varied nutrient availability. New data are needed that show how variation in resource ratios affect the elemental composition of recently isolated bacterial strains or natural bacterial communities.

Bacteria can regulate their biomass composition homeostatically so that it is within a narrower range than the resource ratios present in the environment (Makino et al., 2003). The degree of C:P homeostasis $\left(H^{\prime}\right)$ exhibited by a population of organisms is 
derived from the equation:

$H^{\prime}=\frac{1}{m}$

where $m$ is the slope of $\log \mathrm{C}: \mathrm{P}_{\mathrm{R}}$ versus $\log \mathrm{C}: \mathrm{P}_{\mathrm{B}}$ scatterplot. $H^{\prime} \gg 1$ represents strong elemental homeostasis and suggests that a population is controlling $\mathrm{C}: \mathrm{P}_{\mathrm{B}}$ in a much more narrow range than the variability occurring in $\mathrm{C}: \mathrm{P}_{\mathrm{R}}$. Conversely, $H^{\prime} \approx 1$ represents weak or no elemental homeostasis and suggests that the $\mathrm{C}: \mathrm{P}_{\mathrm{B}}$ of a population is effectively identical to $\mathrm{C}: \mathrm{P}_{\mathrm{R}}$ (Sterner and Elser, 2002).

The C:P homeostasis, or the lack thereof, in bacteria should influence the fate of these elements in the environment (Figure 1). For example, strong homeostasis at a low $\mathrm{C}: \mathrm{P}_{\mathrm{B}}$ by bacteria would be an excellent strategy for rapid growth when $\mathrm{P}$ is abundant, but would require that these organisms slow or halt growth while waiting for available $\mathrm{P}$ during $\mathrm{P}$ deficiency, thereby decreasing their growth efficiency (BGE; ratio of bacterial biomass production to respiration). Conversely, weak homeostatic regulation of $\mathrm{C}: \mathrm{P}_{\mathrm{B}}$ by bacteria would result in more biomass production per unit $\mathrm{P}$ during $\mathrm{P}$ deficiency, allowing bacteria to maintain a relatively high BGE, but during $\mathrm{P}$ sufficiency growth efficiency would decrease due to a low $C: \mathrm{P}_{\mathrm{B}}$. However, weak $\mathrm{C}: \mathrm{P}_{\mathrm{B}}$ homeostasis would enable bacteria to accumulate $\mathrm{P}$ during $\mathrm{P}$ sufficiency. Quantifying these patterns of bacterial stoichiometry is fundamental to understanding how bacterial $\mathrm{P}$ immobilization or mineralization may affect ecosystem functions, such as primary production, on a global scale. The objective of this study was to quantify the C:P stoichiometry of heterotrophic bacteria across a range of ecologically relevant resource C:P ratios. We combined stoichiometric theory with continuous culture growth of recently isolated bacteria to determine the relative $\mathrm{P}$ composition of bacterial cells and the degree to which bacteria regulate their elemental composition homeostatically.

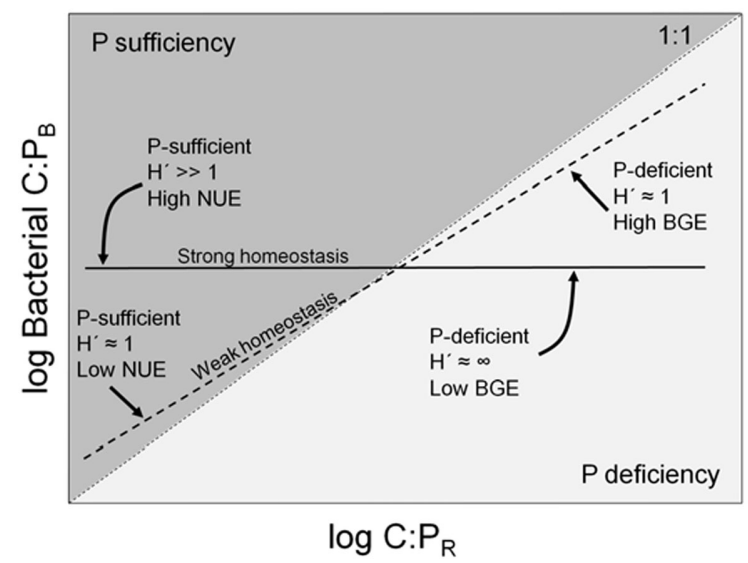

FIGURE 1 | Conceptual model of C:P stoichiometry in heterotrophic bacteria modified from Sterner and Elser (2002). The dotted line represents a 1:1 relationship between resource $C: P$ and bacterial $C: P$. The horizontal solid line indicates strict homeostatic regulation of $C: P$ by bacteria $\left(H^{\prime} \gg 1\right)$ and the dashed line indicates weak homeostatic control of $\mathrm{C}: \mathrm{P}$ by bacteria $\left(H^{\prime} \approx 1\right)$. BGE, bacterial growth efficiency and NUE, nutrient use efficiency.

\section{MATERIALS AND METHODS} BACTERIAL ISOLATIONS, CULTURE CONDITIONS, AND GROWTH RATES

Bacterial strains were isolated from several freshwater lakes in $\mathrm{MN}$ and VA, USA. Bacterial cultures were established by first streaking water samples onto undefined culture media (Difco nutrient agar, cellulose + Difco nutrient agar, or LB agar). Individual colonies were harvested from plates after visible growth had developed and transferred onto a new plate. This process was repeated two to three times in order to isolate individual bacterial strains. Bacterial isolates were identified by $16 \mathrm{~S}$ rRNA gene sequences as described previously (Ghosh and LaPara, 2007). Briefly, genomic DNA was purified from each bacterial strain and used as template for PCR targeting the nearly complete $16 \mathrm{~S}$ rRNA gene using primers $8 \mathrm{~F}$ ( $5^{\prime}$-AGA GTT TGA TCC TGG CTC AG-3') and 1522R (5'-AAG GAG GTG ATC CAG CCG CA- $\left.3^{\prime}\right)$. These PCR products were then purified using a GeneClean II kit (MP Biomedicals; Irvine, CA, USA) and used as template for nucleotide sequence analysis using primers 338F ( $5^{\prime}$-ACT CCT ACG GGA GGC AGC AG-3') and 907R (5'-CCG TCA ATT CCT TTR AGT TT-3'). Sequencing was performed at the Advanced Genetic Analysis Center at the University of Minnesota using an ABI 3100 Genetic Analyzer (Applied Biosystems, Foster City, CA, USA). Consensus sequences from bi-directional sequence information were then compared with sequences obtained from the GenBank database using the BLASTN program (Benson et al., 1999) in order to determine the phylogenetic affiliation of the isolate.

Isolates were transferred to plates containing defined, P-rich $(\mathrm{C}: \mathrm{P}=10)$ culture media (Tanner, 2007), then grown to their maximum density on the same media in liquid form. Stock samples were collected from these liquid cultures and stored at $-80^{\circ} \mathrm{C}$ with $15 \%$ glycerol. Prior to experiments, a single isolate stock was thawed and streaked onto a plate containing P-rich, defined culture media. Cultures were grown at $25^{\circ} \mathrm{C}$ until there was visible growth and then refrigerated for no more than 90 days. Although we isolated over 100 strains, we chose six isolates for experimentation that were phylogenetically diverse. These six isolates represented five genera from three different bacterial phyla. For all experiments, a single colony was extracted from a plate and grown for $24-36 \mathrm{~h}$ in defined, $\mathrm{P}$-rich $(\mathrm{C}: \mathrm{P}=10)$, liquid media. One milliliter of this liquid culture was then used to seed continuous cultures ( $100 \mathrm{ml}$ chemostats). The use of continuous culture chemostats allowed us to control the growth rates of organisms in an ecologically relevant range. Prior to experiments, the maximum growth rate $\left(\mu_{\max }\right)$ of individual strains on P-rich defined media was determined by measuring the change in biomass [measured as optical density (O.D.) at $600 \mathrm{~nm}$ ] of batch cultures over a 24- to 36-h period.

\section{CHEMOSTAT EXPERIMENTS}

A replicated chemostat experiment was conducted using one isolate (Arthrobacter sp.) to determine the degree of variability in biomass [measured as particulate carbon (PC) from cultures], bacterial phosphorus [measured as particulate phosphorus (PP) from cultures], and C: $\mathrm{P}_{\mathrm{B}}$ (molar ratio of $\mathrm{PC}$ and $\mathrm{PP}$ ) at three discrete levels $C: \mathrm{P}_{\mathrm{R}}$. Experiments were conducted in a temperature controlled room at $25^{\circ} \mathrm{C}$. The dissolved organic $\mathrm{C}$ concentration of culture media was kept constant ( $27 \mathrm{mM} \mathrm{C}$ from glucose) across all 
treatments but the $\mathrm{P}$ concentration of the culture media was modified to achieve C: $\mathrm{P}_{\mathrm{R}}$ of $10(n=4), 100(n=4)$, and $1000(n=5)$. Dilution rates of all chemostats were set at $25 \% \mu_{\max }\left(0.1 \mathrm{~h}^{-1}\right.$ for Arthrobacter sp.). Filtered air was continuously pumped into chemostats to aerate and homogenize cultures. Experimental conditions were maintained until biomass (measured O.D. of chemostat effluent) was stable for $24 \mathrm{~h}$, which resulted in experiments that lasted between 4 and 6 days and provided 5-15 complete flushes of the chemostats. Duplicate culture samples from each chemostat were vacuum filtered $(<250 \mathrm{mmHg}$ ) onto pre-combusted GF/F filters for PC analyses and onto acid-washed GF/F filters for PP analysis. PC was measured on a Perkin Elmer Elemental Analyzer 2400 CHN. PP was measured colorimetrically with molybdenum blue (APHA 2005) following acid-persulfate digestion.

Six different unreplicated P-gradient experiments were conducted with each of the six bacterial isolates (population Pgradient experiments), where populations of the individual isolates were grown across a gradient of $\mathrm{P}$ concentrations. The $\mathrm{P}$ concentration of defined liquid culture media was modified to achieve $C: P_{R}$ ratios of $10,25,50,100,250,500,750,1000,2500$, and 5000 based on the expected maximum range of variability in nature (Makino et al., 2003). Chemostat dilution rates were set at $25 \% \mu_{\max }$ for each isolate and operated and sampled as described above.

A P-gradient experiment was also conducted using a mixedculture of Arthrobacter sp. and Flavobacterium sp.-51 (mixedculture P-gradient experiment). The experimental gradient and experimental procedure was identical to the population P-gradient experiments except that equivalent amounts of both bacterial isolates were used to inoculate the chemostats simultaneously. The equivalent amounts of Arthrobacter sp. and Flavobacterium sp.-51 cultures were derived by adjusting the seed volumes based on the O.D. of each of the pure isolate liquid cultures at the time of seeding in order to achieve equally weighted initial biomass of both isolates. In addition to the $\mathrm{C}$ and $\mathrm{P}$ measurements from mixedculture experiments, we also measured the relative abundance of each bacterial strain using amplified ribosomal DNA restriction analysis (ARDRA) as described by Fernandez et al. (1999). Briefly, genomic DNA was extracted and purified as described above. PCR was then used to amplify a fragment of the 16S rRNA gene using primers $8 \mathrm{~F}$ and $907 \mathrm{R}$. These PCR products were purified (GeneClean II) and digested with MseI restriction enzyme. Digested DNA was then resolved on 1.5\% agarose gels stained with ethidium bromide and compared results obtained from pure cultures (as positive controls).

\section{STATISTICAL ANALYSES}

The effects of varying $C: P_{R}$ on bacterial biomass as $P C$, bacterial $\mathrm{P}(\mathrm{PP})$, and $\mathrm{C}: \mathrm{P}_{\mathrm{B}}$ in the replicated experiment were tested with a one-way ANOVA's using PROC GLM in SAS 9.1 (SAS, 2003). Differences among individual means were tested using the REGWQ multiple comparison procedure controlling family wise error at $\alpha=0.05$. The effect of varying $\mathrm{C}: \mathrm{P}_{\mathrm{R}}$ on bacterial biomass as $\mathrm{PC}$ in the gradient experiments was assessed across all isolates with a one-way ANOVA using PROC GLM in SAS (SAS 2003). Differences among mean bacterial biomass across $C: P_{R}$ were tested using the REGWQ multiple comparison procedure controlling family wise error at $\alpha=0.05$. The effect of varying $\mathrm{C}: \mathrm{P}_{\mathrm{R}}$ on bacterial phosphorus (PP) in the gradient experiments was assessed across all isolates with regression analysis by fitting an exponential decay function to mean PP data for all isolates.

Data from these experiments were also separated into Psufficient and P-deficient cultures based on the results of the bacterial biomass ANOVA and a visual inspection of the C: $P_{R}$ versus $\mathrm{C}: \mathrm{P}_{\mathrm{B}}$ scatterplot. A two-way ANOVA was conducted to examine if differences in $C: \mathrm{P}_{B}$ were caused by differences among isolates or differences in $\mathrm{P}$ availability (P-sufficient or P-deficient), or if there was a significant interaction between sources of variation. Differences among mean $\mathrm{C}: \mathrm{P}_{\mathrm{B}}$ were tested when omnibus $F$-tests were statistically significant at $\alpha=0.05$ using the REGWQ multiple comparison procedure controlling family wise error at $\alpha=0.05$.

The relationship between $\log C: \mathrm{P}_{\mathrm{R}}$ and $\log \mathrm{C}: \mathrm{P}_{\mathrm{B}}$ for all cultures was quantified using locally weighted regression (LOESS) in Sigma Plot 10.0 with a sampling proportion of 0.5 and a first order polynomial function (Systat Software, Inc., San Jose, CA, USA). When this relationship appeared linear across the entire range of $C: P_{R}$, a linear regression was fit to the entire dataset using PROC GLM in SAS 9.1 (SAS 2003). In instances when the relationship between $\log C: P_{R}$ and $\log C: P_{B}$ was not linear across the entire range of $C: P_{R}$, separate linear regressions were generated between $\log \mathrm{C}: \mathrm{P}_{\mathrm{R}}$ and $\log \mathrm{C}: \mathrm{P}_{\mathrm{B}}$ for P-sufficient and P-deficient cultures using PROC GLM in SAS 9.1 (SAS 2003). The degree of $\mathrm{C}: \mathrm{P}_{\mathrm{B}}$ homeostasis $\left(H^{\prime}\right)$ exhibited by each isolate was calculated as described previously using the slope from the appropriate linear regression equations. The C:P threshold element ratio (TER) for each isolate, which approximates the element ratio at which organisms transition between $\mathrm{C}$ and $\mathrm{P}$ limitation, was estimated as the value at which $C: P_{B}$ was approximately equal to $C: P_{R}$ according to the LOESS regression between $\log C: P_{R}$ versus $\log C: P_{B}$. The $\mathrm{C}: \mathrm{P}$ reported here is an underestimate of the actual $\mathrm{C}: \mathrm{P}$ TER of an organism because it focuses on the $\mathrm{C}$ requirements for biomass and ignores the $\mathrm{C}$ requirements for metabolism.

\section{RESULTS}

\section{POPULATION STOICHIOMETRY EXPERIMENTS}

Arthrobacter sp. biomass (as PC) in chemostats was not different among different $C: \mathrm{P}_{R}$ when $\mathrm{C}: \mathrm{P}_{\mathrm{R}}$ was $\leq 100$, but was $6 \times$ lower when $\mathrm{C}: \mathrm{P}_{\mathrm{R}}$ was 1000 (Figure 2A). Arthrobacter sp. P content in chemostats with $\mathrm{C}: \mathrm{P}_{\mathrm{R}}=10$ were $6 \times-60 \times$ greater than Arthrobacter sp. $\mathrm{P}$ content in chemostats with $\mathrm{C}: \mathrm{P}_{\mathrm{R}}=100$ and 1000, respectively (Figure 2B). Arthrobacter sp. C: $\mathrm{P}_{B}$ increased with increasing $C: \mathrm{P}_{R}$, but the response of $C: \mathrm{P}_{B}$ to changing $C: \mathrm{P}_{R}$ was not 1:1 (Figure 2C).

The biomass of all bacterial cultures (as PC) in P-gradient experiments was highest when $\mathrm{C}: \mathrm{P}_{\mathrm{R}}$ was $\leq 250$, and exhibited a monotonic decrease with increasing $C: P_{R}$ above this threshold (Figure 3A). Bacterial $\mathrm{P}$ content of all isolates decreased exponentially across the entire range of $C: \mathrm{P}_{\mathrm{R}}$ (Figure $3 \mathrm{~B}$ ). Substantial variability existed in $C: P_{B}$ across all isolates. $C: P_{B}$ was always greater than $C: P_{R}$ in cultures grown at $C: P_{R}<250$, and $C: P_{B}$ was always less than $C: P_{R}$ in all isolate cultures grown at $C: P_{R}>250$ (Figure 3C). All but one isolate (Flavobacterium sp.-51) had a $C: P_{B}$ value less than $C: P_{R}$ when grown at $C: P_{R}=250$. The mean 

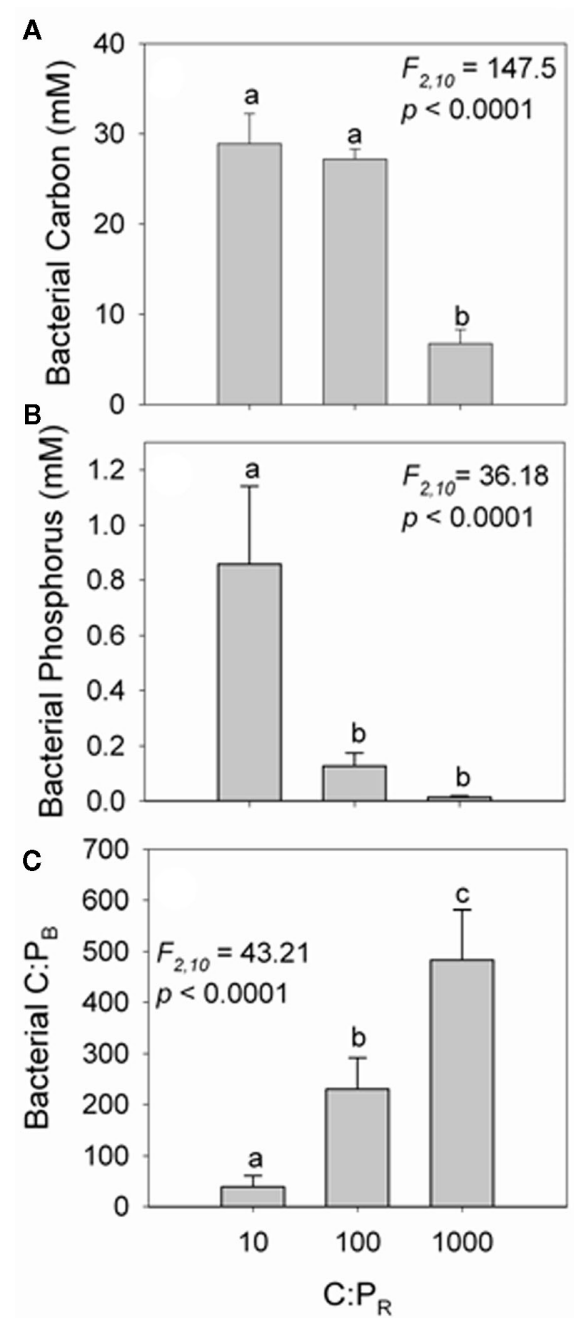

FIGURE 2 | Results of replicated chemostat experiment using Arthrobacter sp. Panels show the effect of three distinct levels of resource C:P on (A) Arthrobacter sp. culture biomass as millimolar particulate C, (B) Arthrobacter sp. biomass phosphorus as millimolar particulate $\mathrm{P}$, and (C) Arthrobacter sp. C: $\mathrm{P}_{\mathrm{B}}$ (molar ratio).

C:P TER for all the isolates combined was 233. Two-way ANOVA revealed no difference in $\mathrm{C}: \mathrm{P}_{\mathrm{B}}$ between different isolates $(F=1.52$; $p=0.2036)$ and no interaction between isolate and $\mathrm{P}$ availability $(F=1.26 ; p=0.3014)$. However, mean $\mathrm{C}: \mathrm{P}_{\mathrm{B}}$ in $\mathrm{P}$-sufficient cultures $(101 \pm 72.3)$ was $4 \times$ lower than mean $\mathrm{C}: \mathrm{P}_{\mathrm{B}}$ in $\mathrm{P}$-deficient cultures $(438 \pm 278 ; F=36.8 ; p<0.0001)$.

The relationship between $\log \mathrm{C}: \mathrm{P}_{\mathrm{R}}$ and $\log \mathrm{C}: \mathrm{P}_{\mathrm{B}}$ in Arthrobacter sp. and Cellvibrio gilvus was approximately linear, and the slope of the best fit line was relatively shallow across the entire range of $\mathrm{C}: \mathrm{P}_{\mathrm{R}}$ (Figure 3D). This indicates that Arthrobacter sp. and C. gilvus exhibited weak homeostatic regulation of $\mathrm{C}: \mathrm{P}_{\mathrm{B}}$ during both $\mathrm{P}$ sufficiency and $\mathrm{P}$ deficiency (Figure 3D). In contrast, the relationship between $\log \mathrm{C}: \mathrm{P}_{\mathrm{R}}$ and $\log \mathrm{C}: \mathrm{P}_{\mathrm{B}}$ in Flavobacterium sp.-64 and Cellulomonas cellulans was non-linear across the entire range of $\mathrm{C}: \mathrm{P}_{\mathrm{R}}$ (Figure 3E). During $\mathrm{P}$ sufficiency, $\log \mathrm{C}: \mathrm{P}_{\mathrm{B}}$ of Flavobacterium sp.-64 and C. cellulans increased almost proportionately (i.e., slope $\sim 1$ ) with $\log \mathrm{C}: \mathrm{P}_{\mathrm{R}}$. However, the slope of this line decreased dramatically for both Flavobacterium sp.-64 and C. cellulans during $\mathrm{P}$ deficiency. This pattern indicates that Flavobacterium sp.-64 and C. cellulans exhibited virtually no homeostasis during P sufficiency but weak homeostasis during $\mathrm{P}$ deficiency (Figure 3E). The relationship between $\log \mathrm{C}: \mathrm{P}_{\mathrm{R}}$ and $\log \mathrm{C}: \mathrm{P}_{\mathrm{B}}$ in Flavobacterium sp.51 and Aeromonas sp. was also non-linear across the entire range of $\mathrm{C}: \mathrm{P}_{\mathrm{R}}$ (Figure 3F). During P sufficiency, $\log \mathrm{C}: \mathrm{P}_{\mathrm{B}}$ of Flavobacterium sp.-51 and Aeromonas sp. increased almost proportionately (i.e., slope $\sim 1$ ) with $\log \mathrm{C}: \mathrm{P}_{\mathrm{R}}$. However, the slope of this line decreased to almost zero for both Flavobacterium sp.-51 and Aeromonas sp. during $\mathrm{P}$ deficiency. This pattern indicates that Flavobacterium sp.-51 and Aeromonas sp. exhibited virtually no homeostasis during $\mathrm{P}$ sufficiency but exceptionally strong homeostasis during $\mathrm{P}$ deficiency (Figure 3F).

\section{MIXED-CULTURE STOICHIOMETRY EXPERIMENT}

The mixed-culture of Arthrobacter sp. and Flavobacterium sp.51 exhibited weak homeostatic regulation of $\mathrm{C}: \mathrm{P}_{\mathrm{B}}$ during $\mathrm{P}$ sufficiency, but strong homeostasis during $\mathrm{P}$ deficiency (Figure 4). The C: $\mathrm{P}_{\mathrm{B}}$ of this mixed-culture resembled the C: $\mathrm{P}_{\mathrm{B}}$ of Arthrobacter sp. during $\mathrm{P}$ sufficiency, but more closely resembled the $\mathrm{C}: \mathrm{P}_{\mathrm{B}}$ of Flavobacterium sp.-51 during $\mathrm{P}$ deficiency. Cultivationindependent community analysis using ARDRA confirmed that Arthrobacter sp. dominated the mixed-culture when C: $\mathrm{P}_{\mathrm{R}}<250$ $\left(\log \mathrm{C}: \mathrm{P}_{\mathrm{R}}<2.4\right)$, but Flavobacterium sp.-51 dominated the mixedculture when $C: P_{R} \geq 250\left(\log C: P_{R} \geq 2.4\right.$; Figure 4).

\section{DISCUSSION}

Phosphorus immobilization or mineralization by bacteria can have profound effects on ecosystem functions such as primary productivity (Cotner and Biddanda, 2002; van der Heijden et al., 2008). However, other than simple experiments using E. coli (Makino et al., 2003) and P. fluorescens (Chrzanowski and Kyle, 1996), the biological stoichiometry of bacteria, which controls the balance $\mathrm{P}$ immobilization and mineralization in microbial heterotrophs, has been largely ignored. The reasons that it has been ignored is due to the difficulty of measuring bacterial stoichiometry in natural systems, and the notion that bacteria in nature are both nutrient-rich and relatively invariant in nutrient content. The traditional paradigm of bacterial stoichiometry has been that bacteria are P-rich, with C:P ratios ranging from 15 to 70 (Tuomi et al., 1995; Vadstein, 2000), and that bacteria regulate their elemental composition homeostatically within a relatively narrow range (Makino et al., 2003). More recent studies have indicated that bacteria may actually be much less P-rich than previously thought (Gundersen et al., 2002; Løvdal et al., 2007; Cotner et al., 2010). Our study indicates that P-limited bacteria are neither P-rich nor are bacteria invariant in nutrient content. Rather, the elemental composition of bacteria can vary substantially depending on what element (carbon or phosphorus in this study) is limiting growth and the growth strategies of individual bacteria that are dominant (elemental homeostasis or non-homeostasis).

If bacteria in nature were always P-rich, as has been suggested from experiments with model organisms (Chrzanowski and Kyle, 1996; Makino et al., 2003), taxa should be P-limited when C: $P_{R}$ ratios are $>50-100$. Our results show that a decrease in bacterial 
A
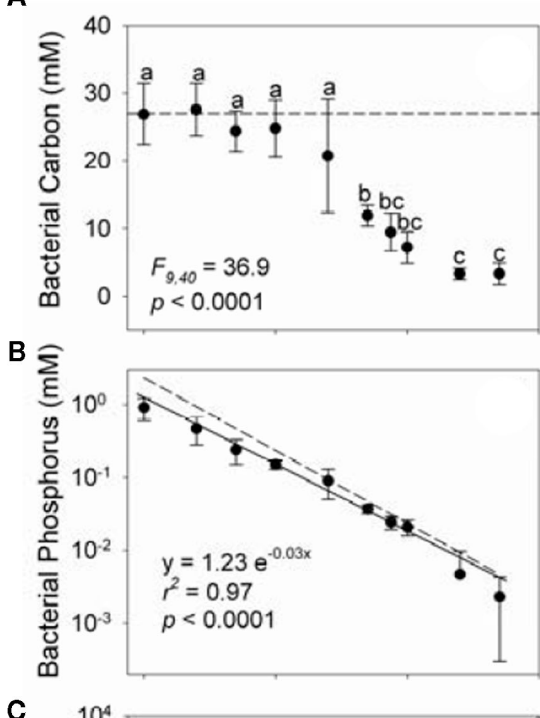

C

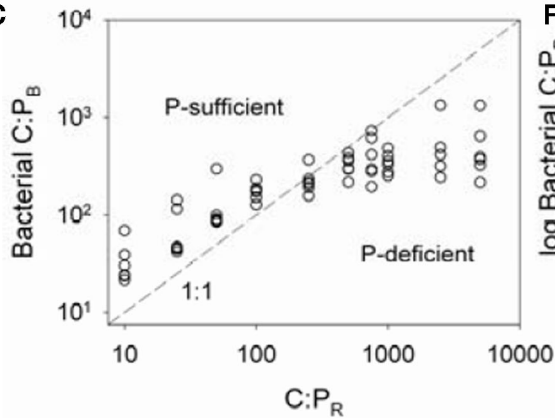

D
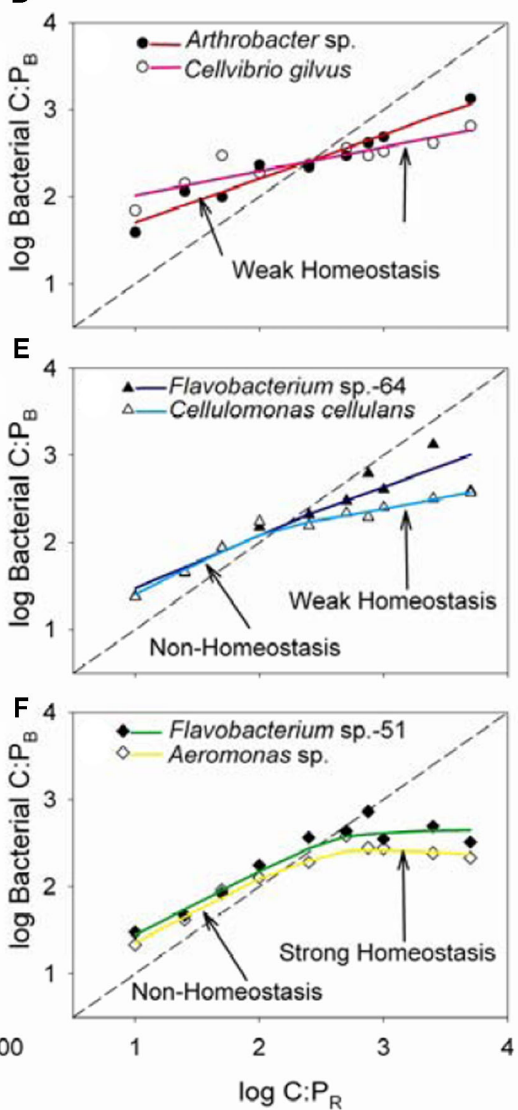

FIGURE 3 | Results of population gradient experiments. Panels on left show the effect of varying resource $C: P$ on (A) mean biomass of all bacterial isolates, (B) mean particulate $\mathrm{P}$ concentration of all bacterial isolate cultures, and (C) bacterial C:P (molar ratio) of all isolates. Panels on right show the effect of varying resource $\mathrm{C}: \mathrm{P}$ (log transformed) on bacterial $C: P$ (log transformed), indicating three distinct patterns of bacterial stoichiometry: (C) Weak homeostasis of bacterial C:P across all levels of resource $C: P$, (D) Weak or no homeostasis during $P$ sufficiency, but weak homeostasis during $P$ deficiency, and (E) No homeostasis during $P$ sufficiency, but strong homeostasis during $P$ deficiency. Dashed lines in $(\mathbf{A}, \mathbf{B})$ represent the culture dissolved organic $\mathrm{C}$ and dissolved $\mathrm{P}$ concentrations, respectively. Replicates at each level of resource $C: P$ in $(\mathbf{A}, \mathbf{B})$ represent one observation from each cultured isolate. Dashed lines in (C-F) represent the 1:1 slope line. biomass occurred only when $\mathrm{C}: \mathrm{P}_{\mathrm{R}}>250$, suggesting that cellular bacterial demand for $\mathrm{P}$ can be much lower than is often assumed. Furthermore, bacterial $\mathrm{P}$ content decreased rapidly with increasing $C: P_{R}$, which means that bacterial $C: P_{B}$ was always greater than $C: P_{R}$ when $C: P_{R}<250$ and less than $C: P_{R}$ when $C: P_{R} \geq 250$. This shows that the stoichiometry of individual bacterial populations is somewhat flexible with regard to $\mathrm{P}$ demand. Mean $\mathrm{C}: \mathrm{P}_{\mathrm{B}}$ in $\mathrm{P}-$ sufficient cultures $(101 \pm 72.3)$ was $4 \times$ lower than mean $\mathrm{C}: \mathrm{P}_{\mathrm{B}}$ in P-deficient cultures $(438 \pm 278)$, and $\mathrm{C}: \mathrm{P}_{\mathrm{B}}$ in some of the $\mathrm{P}$ limited cultures was $>500: 1$, providing further evidence that these organisms could grow with very little $\mathrm{P}$ in biomass.

Four of the six bacterial isolates in this study accumulated excess $\mathrm{P}$ under P-sufficient conditions, i.e., non-homeostasis, while the other two strains generated biomass proportionally to $\mathrm{P}$ availability under $\mathrm{P}$ sufficiency, thereby demonstrating $\mathrm{C}: \mathrm{P}_{\mathrm{B}}$ homeostasis. Conversely, four of the six isolates exhibited weak $\mathrm{C}: \mathrm{P}_{\mathrm{B}}$ homeostasis under $\mathrm{P}$ deficiency while two others exhibited very strict $\mathrm{C}: \mathrm{P}_{\mathrm{B}}$ homeostasis during $\mathrm{P}$ deficiency. Several mechanisms have been documented that could explain these patterns. First, bacteria that were non-homeostatic during $\mathrm{P}$ sufficiency may have accumulated excess $\mathrm{P}$ in polyphosphates (Kulaev and Kulakovskaya, 2000) in order to fuel short-term growth or even increase their motility and survival when $\mathrm{P}$ is much less available (Thomas and O'Shea, 2005). Bacteria exhibiting weak homeostasis during $\mathrm{P}$ deficiency may have modified $\mathrm{C}: \mathrm{P}_{\mathrm{B}}$ by increasing their cell size along one axis in order to increase $\mathrm{P}$ affinity and decrease grazing pressure without changing their cell quota (Thingstad et al., 2005). Alternatively, these organisms could increase their cellular $\mathrm{P}$ acquisition machinery, which are composed of P-poor biochemicals (Klausmeier et al., 2004), or even substitute sulfur or nitrogen for $\mathrm{P}$ into lipids in order to use the replaced $\mathrm{P}$ for sustained growth, similar to what has been demonstrated in some marine picocyanobacteria (Van Mooy et al., 2009). 
A

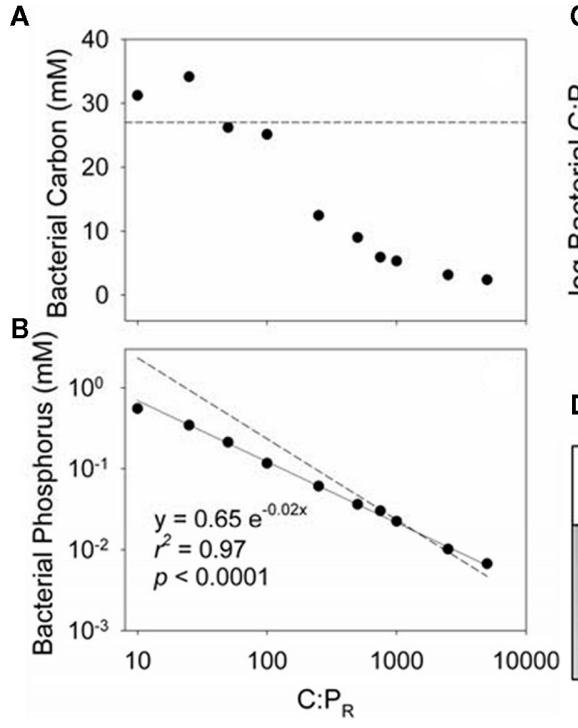

FIGURE 4 | Results of the mixed-culture gradient experiment. Panels on the left show the effect of varying resource $\mathrm{C}$ : $\mathrm{P}$ on (A) mixed-culture biomass, and (B) mixed-culture $P$ composition. (C) Shows the effect of varying resource $C: P$ (log transformed) on bacterial $C: P$ (log transformed) for the mixed-culture

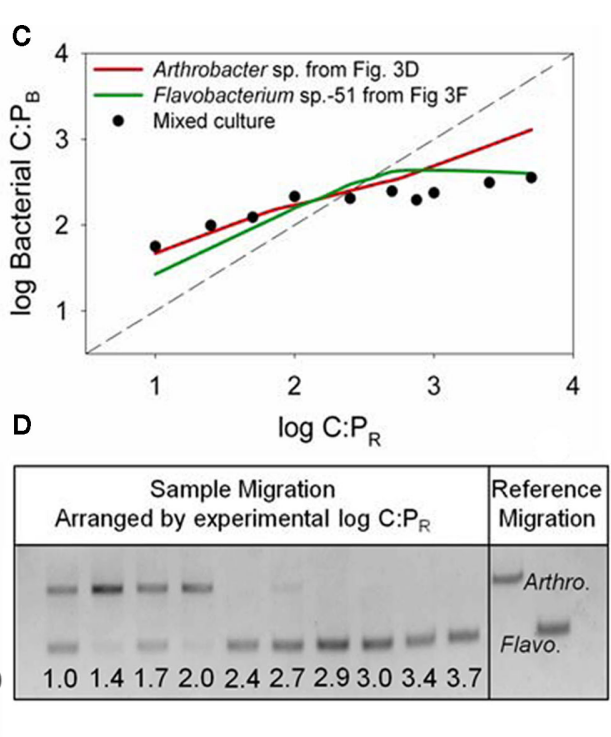

(filled circles) and Arthrobacter sp. (red line) and Flavobacterium sp.-51 (green line) individually. (D) Shows results of amplified ribosomal DNA restriction analysis (ARDRA) for each of the treatments in the mixed-culture experiment and the reference migrations of Arthrobacter sp. and Flavobacterium sp.-51.
The different stoichiometric patterns exhibited among bacterial isolates could represent an important ecological tradeoff. For example, Arthrobacter sp. and C. gilvus remained weakly homeostatic under $\mathrm{P}$ sufficiency (i.e., when C: $\mathrm{P}_{\mathrm{R}}<245$ or $<263$, respectively; Figure 3D). Based on this evidence, stoichiometric theory (Figure 1) tells us that Arthrobacter sp. and C. gilvus likely become net $\mathrm{P}$ mineralizers when $\mathrm{C}: \mathrm{P}_{\mathrm{R}}$ is less than $\sim 250$. In contrast, Flavobacterium sp.-51 and Aeromonas sp. were non-homeostatic when $\mathrm{P}$ was sufficient and effectively accumulated excess $\mathrm{P}$ when $\mathrm{C}: \mathrm{P}_{\mathrm{R}}$ was $<302$ or $<155$, respectively (Figure $3 \mathrm{~F}$ ). Interestingly, Flavobacterium sp.-51 and Aeromonas sp. were strongly homeostatic during $\mathrm{P}$ deficiency (Figure 3F), but Arthrobacter sp. and $C$. gilvus remained weakly homeostatic during $\mathrm{P}$ deficiency (Figure 3D). Therefore, a tradeoff may exist whereby organisms which are very strictly homeostatic during $\mathrm{P}$ deficiency must accumulate excess $\mathrm{P}$ (i.e., no homeostasis) during $\mathrm{P}$ sufficiency. On the other hand, a more flexible organism during $\mathrm{P}$ deficiency (i.e., weak homeostasis) may not need to accumulate excess $\mathrm{P}$ during $\mathrm{P}$ sufficiency and thereby use the available $\mathrm{P}$ to build more biomass and keep their $\mathrm{C}: \mathrm{P}_{\mathrm{B}}$ elevated. Of course, the temporal frequency and duration of transitions between $\mathrm{P}$ sufficiency and $\mathrm{P}$ deficiency may determine which stoichiometric growth strategy is favored in nature, which would have an important effect on $\mathrm{P}$ cycling rates in nature.

If maximizing $\mathrm{C}: \mathrm{P}$ were a fitness goal of bacterial populations, homeostatic bacteria should be favored during $\mathrm{P}$ sufficiency (low $\mathrm{C}: \mathrm{P}_{\mathrm{R}}$ ) and non-homeostatic bacteria should be favored under $\mathrm{P}$ deficiency (high $\mathrm{C}: \mathrm{P}_{\mathrm{R}}$ ) because more biomass is accumulated per unit $\mathrm{P}$ in both cases (Figure 1). However, the results from the mixed-culture experiment showed that the more homeostatic bacteria dominated at both low C: $\mathrm{P}_{\mathrm{R}}$, i.e., C limitation (Arthrobacter sp.), and high $\mathrm{C}: \mathrm{P}_{\mathrm{R}}$, i.e., $\mathrm{P}$ limitation (Flavobacterium sp.-51;
Figure 4). This caused the mixed-culture to behave more homeostatically than individual strains, which is in contrast to theoretical predictions (Danger et al., 2008). However, it is possible that Flavobacterium sp.-51 used $\mathrm{P}$ stored during $\mathrm{P}$ sufficiency (initial growth phase in chemostats) to outcompete Arthrobacter sp. during short-term $\mathrm{P}$ deficiency experienced in these chemostat experiments. Long periods of $\mathrm{P}$ deficiency in nature would probably overextend the ability of $\mathrm{P}$ accumulating bacteria to use stored $\mathrm{P}$ for growth. Therefore, less homeostatic bacteria should dominate under long-term $\mathrm{P}$ deficiency because they create more biomass per unit $\mathrm{P}$ than more homeostatic organisms, which supports the notion that bacterial communities in nature exhibit weak homeostasis in elemental composition (Makino and Cotner, 2004; Danger et al., 2008).

The patterns of bacterial stoichiometry observed in this study help explain why bacteria are so effective at acquiring $\mathrm{P}$ relative to autotrophs in P-limited ecosystems (Cotner and Wetzel, 1992; Nordin et al., 2004). Short-term labile organic C supplements in soils (Dunn et al., 2006), lakes (Stets and Cotner, 2008), and oceans (Thingstad et al., 2008) can decrease primary production due to bacterial competition for limiting nutrients, which is consistent with our observation of $\mathrm{P}$ accumulation by non-homeostatic bacteria during $\mathrm{P}$ sufficiency. However, $\mathrm{C}: \mathrm{P}_{\mathrm{R}}$ depends not only on the absolute $\mathrm{C}$ and $\mathrm{P}$ concentrations, but also on the relative lability of organic C. Labile carbon and microbial biomass generally decrease together with increased distance from the plant rhizosphere (Kennedy, 1998), and bacteria respond more effectively to pulses of phytoplankton-derived $\mathrm{C}$ than pulses of allochthonous $\mathrm{C}$ in the aquatic environment (McCallister and del Giorgio, 2008). This suggests that locations or periods of high primary productivity could increase the realized $\mathrm{C}: \mathrm{P}_{\mathrm{R}}$ for bacteria and effectively induce competitive $\mathrm{P}$ 
Table 1 | Chemostat dilution rates with defined media, homeostasis values $\left(H^{\prime}=1 / m\right.$ where $m$ is the slope of the resource C:P versus bacterial C:P in log-log space) for P-sufficient and P-deficient cultures, and estimated C:P threshold element ratios (TER) for various heterotrophic bacteria.

\begin{tabular}{|c|c|c|c|c|c|c|}
\hline \multirow[t]{2}{*}{ Bacterium } & \multirow[t]{2}{*}{ Dilution rate $\left(\mathrm{h}^{-1}\right)$} & \multicolumn{2}{|c|}{$H^{\prime}$} & \multirow[t]{2}{*}{ TER (C:P) } & \multicolumn{2}{|c|}{ Mean Bacterial C:P } \\
\hline & & P-sufficient & P-deficient & & P-sufficient & P-deficient \\
\hline Arthrobacter sp. ${ }^{1}$ & 0.10 & 1.99 & 1.99 & 245 & $121 \pm 80$ & $548 \pm 448$ \\
\hline Cellvibrio gilvus ${ }^{1}$ & 0.05 & 3.61 & 3.61 & 263 & $174 \pm 96$ & $379 \pm 143$ \\
\hline Vibrio splendidus ${ }^{2}$ & 0.02 & $\infty^{5}$ & $3.13^{5}$ & $241^{5}$ & $217 \pm 50^{5}$ & $283 \pm 103^{5}$ \\
\hline Cellulomonas cellulans ${ }^{1}$ & 0.06 & 1.66 & 3.74 & 138 & $82 \pm 66$ & $252 \pm 80$ \\
\hline Flavobacterium sp.-64 ${ }^{1}$ & 0.05 & 1.65 & 1.90 & 162 & $77 \pm 56$ & $542 \pm 412$ \\
\hline Pseudomonas fluorescens ${ }^{3}$ & $0.03-0.09$ & \multicolumn{2}{|c|}{$5.17^{6}$} & $70^{7}$ & $40^{8}$ & $178^{8}$ \\
\hline Flavobacterium sp.- $51^{1}$ & 0.06 & 1.40 & 14.7 & 302 & $84 \pm 65$ & $451 \pm 150$ \\
\hline Aeromonas sp. ${ }^{1}$ & 0.05 & 1.47 & 26.3 & 155 & $71 \pm 48$ & $265 \pm 67$ \\
\hline Escherichia coli ${ }^{4}$ & $0.5-1.5$ & \multicolumn{2}{|c|}{$\infty^{6}$} & $50^{7}$ & $55^{8}$ & $55^{8}$ \\
\hline
\end{tabular}

Homeostasis values for $E$. coli and P. fluorescens derived from literature data could only be estimated across all levels of resource C:P.

${ }^{1}$ This study.

${ }^{2}$ Lovdal et al. (2007).

${ }^{3}$ Chrzanowski and Kyle (1996).

${ }^{4}$ Makino et al. (2003).

${ }^{5}$ Calculated from data in Table 2 of Løvdal et al. (2007).

${ }^{6} \mathrm{H}^{\prime}$ not evaluated separately for P-sufficient or P-deficient cultures.

${ }^{7} T E R$ estimated graphically as the point of intersection between least squares regression line and 1:1 line

${ }^{8}$ Approximated from data in Figure 5 of Makino et al. (2003).

uptake by bacteria, potentially diminishing primary production. But, decreased primary production also should reduce labile carbon availability, which effectively decreases $C: P_{R}$ and promotes bacterial P mineralization.

Given that primary production in many ecosystems can experience frequent P limitation (Elser et al., 2007), and that a large proportion of biomass in all ecosystems is comprised of heterotrophic bacteria (Whitman et al., 1998; Biddanda et al., 2001), our study suggests that these feedbacks may constitute a major control on the global C cycle. Bacterial stoichiometry may play a particularly important role in this dynamic by providing a biogeochemical "set point" around which environmental variation is regulated. Although our results are limited to organisms that could be cultivated, these bacteria included five different genera representing three bacterial phyla (Table 1). Therefore, genetically diverse microbial communities may also be stoichiometrically diverse, but greater exploration of the potential stoichiometric diversity of microbes is desperately needed. Furthermore, more work is needed to understand how these bottom-up controls may interact with top-down pressures to influence bacterial stoichiometry.

\section{REFERENCES}

Benson, D. A., Boguski, M. S., Lipman, D. J., Ostell, J., Ouellette, B. F. F., Rapp, B. A., and Wheeler, D. L. (1999). GenBank. Nucleic Acids Res. $27,12-17$.

Biddanda, B., Ogdahl, M., and Cotner, J. (2001). Dominance of bacterial metabolism in oligotrophic relative to eutrophic waters.
Limnol.

Oceanogr.

46 , 730-739.

Chrzanowski, T. H., and Grover, J. P. (2008). Elemental content of Pseudomonas fluorescens varies with growth rate and temperature: a replicated chemostat experiment addressing ecological stoichiometry. Limnol. Oceanogr. 54, 1242-1251.
The C:P TER of recently isolated strains was much higher than that observed in model organisms (Table 1), and some bacteria showed similar degrees of homeostasis under both $\mathrm{C}$ and $\mathrm{P}$ limitation, but most strains were more homeostatic under $\mathrm{P}$ limitation than $\mathrm{C}$ limitation. While our work suggests that this set point may vary within and across strains, understanding how these stoichiometric relations are maintained or not in bacterial communities has important implications to the net balance of nutrient consumption or regeneration in ecosystems.

\section{ACKNOWLEDGMENTS}

Andre Amado aided in sample collection from Minnesota lakes and isolating bacteria. Debra Wohl (Elizabethtown College, PA, USA) provided bacteria isolated from Westhampton Lake in Richmond, VA, USA. Andrea Little, Sandy Brovold, and Nick Rossi assisted with laboratory analyses. The study was funded through a National Science Foundation grant to James B. Cotner (DEB-0519041). Partial support was also provided through a National Science Foundation grant to J. Thad Scott (DEB-1020722). 
with a nutrient composition similar to seston. Front. Microbiol. 1:132. doi:10.3389/fmicb.2010.00132

Cotner, J. B., Makino, W., and Biddanda, B. A. (2006). Temperature affects stoichiometry and biochemical composition of Escherichia coli. Microb. Ecol. 52, 26-33.

Cotner, J. B., and Wetzel, R. G. (1992). Uptake of dissolved inorganic and organic phosphorus compounds by phytoplankton and bacterioplankton. Limnol. Oceanogr. 37, 232-243.

Danger, M., Daufresne, T., Lucas, F., Pissard, S., and LaCroix, G. (2008). Does Leibeg's law of the minimum scale up from species to communities? Oikos 117, 1741-1751.

Dunn, R., Mikola, J., Bol, R., and Bardgett, R. D. (2006). Influence of microbial activity on plantmicrobial competition for organic and inorganic nitrogen. Plant Soil 289, 321-334.

Elser, J. J., Bracken, M. E. S., Cleland, E. E., Gruner, D. S., Harpole, W. S., Hillebrand, H., Ngai, J. T., Seabloom, E. W., Shurin, J. B., and Smith, J. E. (2007). Global analysis of nitrogen and phosphorus limitation of primary producers in freshwater, marine, and terrestrial ecosystems. Ecol. Lett. 10, 1135-1142.

Fernandez, A. A., Huang, S., Seston, S., Xing, J., Hickey, R. F., Criddle, C. A., and Tiedje, J. (1999). How stable is stable? Function versus community composition. Appl. Environ. Microbiol. 66, 4058-4067.

Ghosh, S., and LaPara, T. M. (2007). The effects of subtherapeutic antibiotic use in farm animals on the proliferation and persistence of antibiotic resistance among soil bacteria. ISME J. 1, 191-203.

Gundersen, K., Heldal, M., Norland, S., Purdie, D. A., and Knap, A. H. (2002). Elemental C, N, and $\mathrm{P}$ cell content of individual bacteria collected at the Bermuda Atlantic Time-series Study
(BATS) site. Limnol. Oceanogr. 47, 1525-1530.

Kennedy, A. C. (1998). "The rhizosphere and spermosphere," in Principles and Applications of Soil Microbiology, eds D. M. Sylvia, J. J. Fuhrmann, P. G. Hartel, and D. A. Zuberer (Upper Saddle River: Prentice-Hall, Inc.), 389-407.

Klausmeier, C. A., Litchman, E., Daufresne, T., and Levin, S. A. (2004). Optimal nitrogento-phosphorus stoichiometry of phytoplankton. Nature 429, 171-174.

Kulaev, I., and Kulakovskaya, T. (2000). Polyphosphate and the phosphate pump. Annu. Rev. Microbiol. 54, 709-734.

Løvdal, T., Skjoldal, E. F., Heldal, M., Norland, S., and Thingstad, T. F. (2007). Changes in morphology and elemental composition of Vibrio splendidus along a gradient from carbon-limited to phosphatelimited growth. Microb. Ecol. 55, 152-161.

Makino, W., Cotner, J. B., Sterner, R. W., and Elser, J. J. (2003). Are bacteria more like plants or animals? Growth rate and resource dependence of bacterial C:N:P stoichiometry. Funct. Ecol. 17, 121-130.

Makino, W., and Cotner, J. B. (2004). Elemental stoichiometry of a heterotrophic bacterial community in a freshwater lake: implications for growth- and resource-dependent variations. Aquat. Microb. Ecol. 34, 33-41.

McCallister, S. L., and del Giorgio, P. A. (2008). Direct measurement of the $\delta 13 \mathrm{C}$ signature of carbon respired by bacteria in lakes: linkages to potential carbon sources, ecosystem baseline metabolism, and $\mathrm{CO} 2$ fluxes. Limnol. Oceanogr. 53, 1204-1216.

Nordin, A., Schmidt, I. K., and Shaver, G. R. (2004). Nitrogen uptake by arctic soil microbes and plants in relation to soil nitrogen supply. Ecology 85, 955-962.
Sterner, R. W., and Elser, J. J. (2002). Ecological Stoichiometry: The Biology of Elements from Molecules to the Biosphere. Princeton: Princeton University Press.

Stets, E. G., and Cotner, J. B. (2008). The influence of dissolved organic carbon on bacterial phosphorus uptake and bacterial-phytoplankton dynamics in two Minnesota lakes. Limnol. Oceanogr. 53, 137-147.

Tanner, R. S. (2007). "Cultivation of bacteria and fungi," in Manual of Environmental Microbiology, eds C. J. Hurst, R. L. Crawford, J. L. Garland, D. A. Lipson, A. L. Mills, and L. D. Stetzenbach (Washington, DC: ASM press), 69-78.

Thingstad, T. F., Bellerby, R. G. J., Bratbak, G., Børsheim, K. Y., Egge, J. K., Heldal, M., Larsen, A., Neill, C., Nejstgaard, J., Norland, S., Sandaa, R.-A., Skjoldal, E. F., Tanaka, T., Thyrhaug, R., and Topper, B. (2008). Counterintuitive carbonto-nutrient coupling in an Arctic pelagic ecosystem. Nature 455, 387-390.

Thingstad, T. F., Øvreås, L., Egge, J. K., Løvdal, T., and Heldal, M. (2005). Use of non-limiting substrates to increase size; a generic strategy to simultaneously optimize uptake and minimize predation in pelagic osmotrophs. Ecol. Lett. 8, 675-682.

Thomas, M. R., and O'Shea, E. K. (2005). An intracellular phosphate buffer filters transient fluctuations in extracellular phosphate levels. Proc. Nat. Acad. Sci. U.S.A. 102, 9565-9570.

Tuomi, P., Fagerbakke, K. M., Bratbak, G., and Heldal, M. (1995). Nutritional enrichment of a microbial community: the effects on activity, elemental composition, community structure, and virus production. FEMS Microbiol. Ecol. 16, 123-134.

Vadstein, O. (2000). Heterotrophic, planktonic bacteria and cycling of phosphorus: phosphorus requirements, competitive ability and food web interactions. $A d v$. Microb. Ecol. 16, 115-133.

van der Heijden, M. G. A., Bardgett, R. D., and van Straalen, N. M. (2008). The unseen majority: soil microbes as drivers of plant diversity and productivity in terrestrial ecosystems. Ecol. Lett. 11, 296-310.

Van Mooy, B. A. S., Fredricks, H. F., Pedler, B. E., Dyhrman, S. T., Karl, D. M., Koblížek, M., Lomas, M. W., Mincer, T. J., Moore, L. R., Moutin, T., Rappé, M. S., and Webb, E. A. (2009). Phytoplankton in the ocean use non-phosphorus lipids in response to phosphorus scarcity. Nature 458, 69-72.

Whitman, W. B., Coleman, D. C., and Wiebe, W. J. (1998). Prokaryotes: the unseen majority. Proc. Nat. Acad. Sci. U.S.A. 95, 6578-6583.

Conflict of Interest Statement: The authors declare that the research was conducted in the absence of any commercial or financial relationships that could be construed as a potential conflict of interest.

Received: 14 November 2011; accepted: 26 January 2012; published online: 22 February 2012.

Citation: Scott JT, Cotner JB and LaPara TM (2012) Variable stoichiometry and homeostatic regulation of bacterial biomass elemental composition. Front. Microbio. 3:42. doi 10.3389/fmicb.2012.00042

This article was submitted to Frontiers in Aquatic Microbiology, a specialty of Frontiers in Microbiology.

Copyright (c) 2012 Scott, Cotner and LaPara. This is an open-access article distributed under the terms of the Creative Commons Attribution Non Commercial License, which permits noncommercial use, distribution, and reproduction in other forums, provided the original authors and source are credited. 